\title{
Integrating Inter-religious Dialogue with Social Action: A Reflection from the Covid-19 Humanitarian Relief Mission
}

Arfah Ab. Majid

To Link this Article: http://dx.doi.org/10.6007/IJARBSS/v11-i12/11892

DOI:10.6007/IJARBSS/v11-i12/11892

Received: 12 October 2021, Revised: 16 November 2021, Accepted: 30 November 2021

Published Online: 08 December 2021

In-Text Citation: (Majid, 2021)

To Cite this Article: Majid, A. A. (2021). Integrating Inter-religious Dialogue with Social Action: A Reflection from the Covid-19 Humanitarian Relief Mission. International Journal of Academic Research in Business and Social Sciences, 11(12), 1468-1487.

\section{Copyright: @ 2021 The Author(s)}

Published by Human Resource Management Academic Research Society (www.hrmars.com)

This article is published under the Creative Commons Attribution (CC BY 4.0) license. Anyone may reproduce, distribute, translate and create derivative works of this article (for both commercial and non0-commercial purposes), subject to full attribution to the original publication and authors. The full terms of this license may be seen at: http://creativecommons.org/licences/by/4.0/legalcode

Vol. 11, No. 12, 2021, Pg. $1468-1487$

Full Terms \& Conditions of access and use can be found at http://hrmars.com/index.php/pages/detail/publication-ethics 


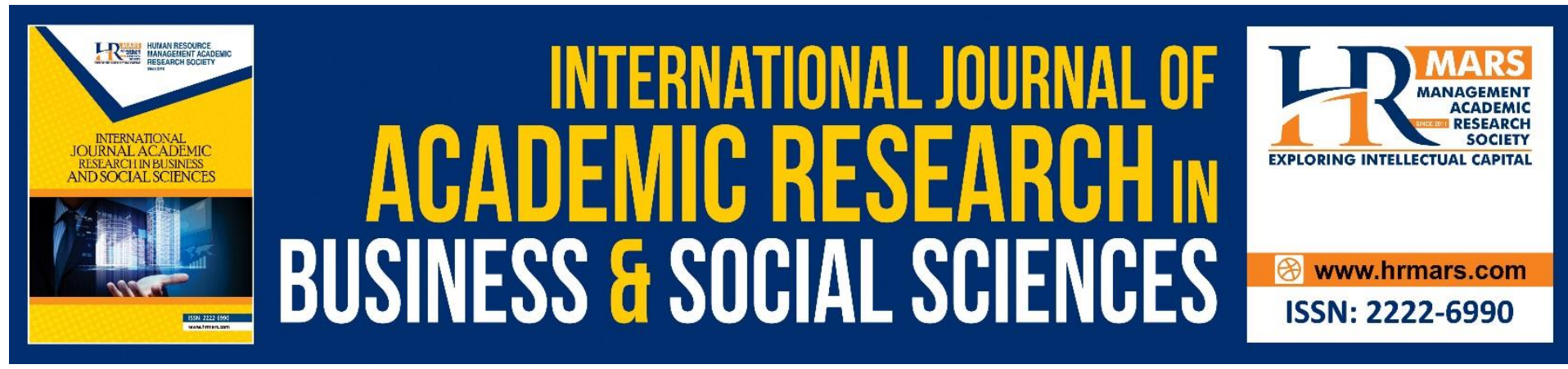

\title{
Integrating Inter-religious Dialogue with Social Action: A Reflection from the Covid-19 Humanitarian Relief Mission
}

\author{
Arfah Ab. Majid \\ Department of Government and Civilization Studies, Faculty of Human Ecology, \\ Universiti Putra Malaysia, 43400 UPM Serdang, Selangor. \\ Email:am_arfah@upm.edu.my
}

\begin{abstract}
Even though the grassroots may not be actively involved in inter-religious dialogue, their inter-religious engagement is reflected in the social action and humanitarian endeavours especially during the COVID-19 outbreak where multiple religious-based organisations have channelled various types of aid. These social action elements can be integrated in the existing models of inter-religious dialogue. However, to realize this idea, the existing design of inter-religious dialogue need to be examined. This study aims at analysing the dialogue designs and determining whether the existing designs have integrated the cooperation and social action. A collective case study was employed and by using purposive sampling technique, ten organizations that were involved in inter-religious dialogue were selected. Data were obtained via interview and document analysis. The finding reveals that the most salient type of inter-religious dialogue in Malaysia is critical-dialogic education without action planning and alliance building stage. The flaw in the dialogue design might affect the effectiveness of the dialogue program. This study therefore, offers a novel and systematic approach for inter-religious dialogue as it proposes a socio-psychological framework to integrate intellectual discourse and social action. The finding also serves as a basis for the development of more appealing inter-religious dialogue for the grassroots.
\end{abstract}

Keywords: Inter-Religious Dialogue, COVID-19, Humanitarian, Cooperation, Social Action

\section{Introduction}

Other than a platform for exploring the truth (Al-Faruqi, 1992), inter-religious dialogue is also a good platform to understand traditions other than one's own (Lochhead, 1988). In Malaysian context, inter-religious dialogue is perceived as a tool to strengthen national unity and integration (Azizan, 2008). Khadijah (2005) for instance states that in order to clarify any misunderstandings in an inter-religious community, a dialogue where people can meet, discuss, exchange opinions and explore the truth while simultaneously preserving peaceful co-existence among the communities is crucial.

Khairulnizam and Suzy (2012) have identified the important roles of inter-religious dialogue and these include the instilling of mutual understanding and correspondence, the promotion 
of co-operation in public affairs, the encouragement to unite and integrate, and the building up of trust for one another in order to live in harmony.

\section{The Reality of the Implementation of Inter-religious Dialogue in Malaysia}

Despite its benefits and significance, inter-religious dialogue is still underrated in this country. The less than encouraging implementation and participation of inter-religious dialogue in Malaysia is apparently influenced by the nature of the dialogue itself which is considered as highly intellectual. Ghazali (2005) for instance describes inter-religious dialogue as an intellectual discourse that involves the meeting of religious representatives. The topics for this dialogue normally revolve around philosophical and theological themes which are not suitable for the grassroots. The participants for dialogue with this nature are also expected to fulfil certain conditions such as well-versed in religious and textual study regarding the sacred scriptures of other religions (Rahimin et al., 2011).

\section{Inter-religious Dialogue, Humanitarianism and Social Action}

Inter-religious dialogue as a matter of fact is part of social action. According to Al-Faruqi (1992), in order to address various needs of humanity, members of diverse religions should be involved in collaborative efforts in applying their religious teachings related to universal and moral values. This cooperative endeavour would transform the role of inter-religious dialogue from shared understanding to action that would benefit every religious group and the world in general (Fletcher, 2012).

Since suffering (e.g., poverty, victimisation, violence and patriarchy) affected everyone regardless of faiths and religions, therefore, people of faith should have the same mission to alleviate this suffering. The action and cooperation in addressing issues of humanity consequently will lead to dialogue (Knitter, 1995). According to Haney (2009), whenever people from different religious background commit to work on projects or address issues of common concern, dialogue of cooperation takes place. During the cooperation, religious orientation will be manifested and its significance in generating positive outcomes will be demonstrated.

Corpuz (2020) opines that, dialogue of action is a genuine commitment to religion in order to achieve a just and humane society. In the midst of the COVID-19 pandemic, universal values such as respecting the rights and responsibilities of each individual and assisting the disadvantaged and most vulnerable members of society are promoted through inter-religious collaborations. As an example, a global Multi-Religious Faith-in-Action COVID-19 Initiative has been launched to increase awareness of the impacts of this pandemic on the world's population especially children. This initiative is a collaboration between Religions for Peace (RfP) and the United Nations Children's Fund (UNICEF). The global partnership on Faith and Positive Change for Children, Families and Communities will become the coordinator of this initiative. Among the members of this global partnership are: Religions for Peace's Interreligious Councils, including senior leaders of the world's religious and spiritual traditions (i.e., Bahai, Buddhist, Christian, Hindu, Islamic, Jain, Jewish, Sikh, Zoroastrian and Indigenous spirituality). This global partnership will counter the COVID-19 pandemic through various ways such as promoting the importance of hygiene and sanitation in accordance with religious teachings and sacred texts that emphasize cleanliness as an element of holiness and providing 
spiritual and emotional care and support for parents, children, the elderly and those who are affected by disruption and distress (UNICEF, 2020).

\section{Religious-based Humanitarian Aids during COVID-19 in Malaysia}

In Malaysian context, the social action and humanitarianism values could be seen in the humanitarian aids and services provided by several religious-based organizations during the Covid-19 outbreak in general and during Movement Control Order (MCO) in particular. Jabatan Kemajuan Islam Malaysia (JAKIM) for instance had launched Tabung Musaadah Covid 19, a religious-based relief program to provide financial support for the affected groups.

Under the same banner of Tabung Musaadah Covid-19, My Care Covid service was also initiated to provide emotional, spiritual and psychological support for the community during MCO. Other than Covid-19 related relief programs, other existing charity programs such as Jabatan Agama Islam Wilayah Persekutuan (JAWI) foodbank programmes continue to serve the vulnerable community during the pandemic (JAKIM, 2020).

The Malaysian Church of Jesus Christ of Latter-day Saints (MCJCLS) mobilized a donation programme to National Kidney Foundation of Malaysia (NKF) and the Association of Social Services and Community Development Gombak District, Selangor, Malaysia. The donation covered 30,000 medical face masks and 200 sets of N95 face masks (MCJCLS, 2020).

A Buddhist organization, Taiwan Buddhist Tzu Chi Foundation Malaysia (TBTCFM), had set up a program known as Covid-19 Response, a donation program to provide equipment for the front liners (e.g., face shields and protective garments), hospital beds, households care assistance, face mask and many more (TBTCFM, 2020). Welfare Committee of Malaysia Hindu Sangam Penang State Council (MHSPSC) also launched a Zero Hunger Programme (Covid-19) which aimed at distributing Rice Packets to unfortunate families affected by Movement Control Order (MCO) (MHSPSC, 2020).

The Sikh community also initiated many programs as part of humanitarian aid mission during Covid-19. For instance, the United Sikhs Malaysia for example, had purchased and loaned medical devices such as pulse oximeters, oxygen concentrators and portable oxygen bags to patients under home quarantine (Nair, 2021).

Humanitarian aids and services provided by these religious-based organizations during the Covid-19 outbreak and MCO in this country has proven that all religions main endeavour is betterment of humanity just as proposed by Al-Faruqi (1992) and Knitter (1995). The collaboration of the religious-based organisations will make a great impact not only in addressing humanitarian crisis such as Covid-19 but also in strengthening inter-religious relations.

The inter-religious cooperation and social action in addressing humanitarian needs are also seen as more feasible for the grassroots instead of intellectual disco urse. Therefore, interreligious cooperation and social action can be a good platform for the grassroots to get involved in inter-religious dialogue. According to Atalia (2017), inter-religious action is inexorably connected to "intra- and inter-religious dialogue, hermeneutical contestation and religious literacy" (p.20). 
Nevertheless, in order to integrate cooperation and social action with dialogue, consequently redesigning the existing models of inter-religious dialogue, a few questions need to be considered:

1. What are the existing types and designs of inter-religious dialogue? Is it merely intellectual discourse or there are other types and designs?

2. Does the existing models of inter-religious dialogue have integrated cooperation and social action?

Present study aims at achieving the following goals

1. To analyse the inter-religious dialogue designs using types of dialogue and four dialogue stages (Zúñiga and Nagda, 2001).

2. To identify the cooperation and social action elements in the existing model of interreligious dialogue.

\section{Materials and Methods \\ Qualitative Method}

In order to explore the design of inter-religious dialogue, the qualitative approach was chosen as process and patterns are best examined with this approach (McMillan \& Weyers, 2007).

\section{Research Design}

Case study research design was employed in this study for a deeper understanding of organizational inter-religious dialogue designs as the case study is associated with a description of the event, program, and process. Since this study involves more than one organization, it is known as "collective case study" design (Stake, 2000).

\section{Sampling}

For this study, purposive sampling technique was adopted. The main criterion in the selection of organizations for this study was the involvement or experience of the organizations in implementing inter-religious dialogue in Malaysia. Ten organizations that met this criterion were identified and the organizations selected are:

1. Higher Education Institutions:

1.1 Centre for Civilizational Dialogue of University of Malaya (CCD)

1.2 Intellectual Youth Club of International Islamic University Malaysia (IYC)

1.3 Majlis Perwakilan Pelajar University Sains Malaysia Kampus Kesihatan (Student Representative Council of University of Science Malaysia Health Campus) (MPP (USM))

1.4 Student Affairs Department Multimedia Universiti Melaka Campus (STAD)

2. Islamic NGOs:

2.1 Islamic Propagation Society International (IPSI)

2.2 Islamic Information Services (IIS)

3. Non-Muslim and Inter-faith NGOs:

3.1. Archdiocesan Ministry of Inter-religious Affairs (AMEIA)

3.2 Inter-faith Spiritual Fellowship (INSaF)

3.3 Malaysian Consultative Council of Buddhism, Christianity, Hinduism, Sikhism and Taoism (MCCBCHST) 
4. Government's Support Organization

4.1 Institut Kemajuan Islam Malaysia (IKIM) (Institute of Islamic Understanding Malaysia)

\section{Data Collection \\ Data Collection Instruments Interview}

In order to ensure cross-case comparability, semi-structured interview was applied. Among the questions constructed were:

i. Can you provide an overview of your dialogue model?

ii. What are the goals of your dialogue model?

iii. Who are the participants?

iv. How are the participants chosen?

v. Can you take me step by step through your dialogue process as if I were a participant? (Pre-session, session, post-session)

vi. What are the activities that you include in the dialogue program?

vii. What are the design principles? (Flexibility, emotional connection, open-ended, safe space, individual/community change, storytelling etc.)

The list of interviewees is as follows:

i. Michael Chua (Ecclesiastical Assistant of AMEIA)

ii. Shah Kirit Kalkulal Govindji (Chief Da'wah Officer of IIS)

iii. Mohd. Sani Badron (Director/Senior Fellow, Centre for Economics and Social Studies of IKIM)

iv. Amir Farid Isahak (Chairman of INSaF) and K. Haridas (Treasurer of INSaF)

v. Kamaruddin Abdulah (President of IPSI)

vi. Fikri Idzhar Darus (Head Bureau of Training and Development of IYC)

vii. Thomas Philips (President of MCCBCHST)

viii. Nizam Shamil Razali (Assistant Manager Student Affairs and Sports Unit of STAD (MMU)) and Mohd. Luthfi Bakar (Assistant Manager Mosque and Accommodation of STAD (MMU))

ix. Nurhamizah Mohamad Rafiuddin, Suraya Mahusin, Muhamad Naim Ab.Razak Muhammad and Huzaifah Mohamad Jan (Former board members of MPP (USM))

x. Amran Muhammad (Deputy Director of CCD)

\section{Document Analysis}

In addition to the interview, this phase of data collection also relies on records and documents related to the dialogue implementation. Among the documents collected were meeting reports (from IYC, STAD (MMU), MPP (USM), CCD); bulletins (from CCD, INSaF); CD collections (from CCD); websites (from AMEIA, INSaF, MPP (USM), IIS); concept papers and program guides (from IKIM), annual reports (from INSaF), booklets or pamphlets (from IPSI, MCCBCHST) and inter-religious dialogue program working papers (from MPP (USM)). These documents compensated for any missing or overlooked information or data during the interview. 


\section{Data Collection Procedures}

All interviewees were provided with Informed Consent and a Research Overview and Participant Information for them to read and sign. Before the interview, the interviewees were told to introduce themselves, state their positions in the organizations and describe their role in the implementation of inter-religious dialogue.

Although the interview guide or protocol was prepared in English, most of the interview sessions were conducted in Malay. The interview sessions conducted in English were with the Ecclesiastical Assistant of AMEIA, Michael Chua, President of IPSI, Kamaruddin Abdullah, INSaF Treasurer, K. Haridas, and the president of MCBCHST, Thomas Philips. All interviews were recorded with permission from the interviewees. The recorded interviews were then transcribed in 'word' format.

Some documents, for the purpose of document analysis, were prepared in advance by several organizations during the visit of the researcher for the interview session such as in the cases of IYC, IPSI, IKIM, MCCBCHST, STAD (MMU) and MPP (USM). However, some documents were not prepared by the organizations during the interview sessions and the researcher had to return on a later date to collect them as in the cases of CCD and INSaF. Some documents were also retrieved online such as those from AMEIA, IIS, MCCBCHST and INSaF. These documents together with the interview transcripts were analysed systematically using the qualitative data analysis method.

\section{Data Analysis}

The data obtained from the interview transcripts and organizational documents were analysed using three-step process of analysis (Miles \& Huberman, 1994). The data was first reduced by summarizing and comparing it to the main framework of this study (i.e., the inter-group dialogue types and four dialogue stages (Zúñiga \& Nagda, 2001: 314-315). (See Table 1). Among the themes that emerged for the design of dialogue include topic, participant, format, goals, duration and activities.

The reduced data was then displayed by developing matrices of various data sets and being compared. The data was also displayed using the cross-case analysis method as this study involves more than one case (collective and multiple case studies). Applying the same principles as within-case analysis, the data gathered from ten organizations were organized in a matrix to analyse the similarities and differences in the inter-religious dialogue types and design by each organization. 
Table 1: Types of Dialogue and Applications for Each Stage

\begin{tabular}{|c|c|c|c|c|}
\hline Types & Collective inquiry & $\begin{array}{l}\text { Critical-dialogic } \\
\text { education }\end{array}$ & $\begin{array}{l}\text { Community building } \\
\text { and social action }\end{array}$ & $\begin{array}{l}\text { Conflict resolution } \\
\text { and peace building }\end{array}$ \\
\hline Stage & & & & \\
\hline $\begin{array}{l}\text { Setting the } \\
\text { environment }\end{array}$ & $\begin{array}{l}\text { Build a container for } \\
\text { dialogue for safety and } \\
\text { trust issues to emerge. } \\
\text { Develop group } \\
\text { consensus. }\end{array}$ & $\begin{array}{l}\text { Develop guidelines for } \\
\text { dialogue. } \\
\text { Build relationship. }\end{array}$ & $\begin{array}{l}\text { Discuss, clarify and set } \\
\text { ground rules. } \\
\text { Share personal beliefs } \\
\text { and experiences } \\
\text { about race and race } \\
\text { relations. }\end{array}$ & $\begin{array}{l}\text { Orient group } \\
\text { members. } \\
\text { Decide to engage in } \\
\text { dialogue. }\end{array}$ \\
\hline $\begin{array}{l}\text { Developing a } \\
\text { common } \\
\text { base }\end{array}$ & $\begin{array}{l}\text { Explore beliefs and } \\
\text { assumptions leading to } \\
\text { public suspension of } \\
\text { judgments. } \\
\text { Dialogue about } \\
\text { personal, work related } \\
\text { or general topics. }\end{array}$ & $\begin{array}{l}\text { Develop a common } \\
\text { language. } \\
\text { Explore multiple social } \\
\text { identities, } \\
\text { commonalities and } \\
\text { differences. }\end{array}$ & $\begin{array}{l}\text { Ask what the state of } \\
\text { race relation in our } \\
\text { community is. } \\
\text { Ask what the nature } \\
\text { of the problem with } \\
\text { race is. }\end{array}$ & $\begin{array}{ll}\text { Map and name } & \text { problems and } \\
\text { relationships. } & \\
\text { Explore and clarify } \\
\text { issues and group } \\
\text { development. }\end{array}$ \\
\hline $\begin{array}{l}\text { Exploring } \\
\text { questions } \\
\text { issues, } \\
\text { conflict }\end{array}$ & $\begin{array}{l}\text { Increase suspension of } \\
\text { judgment and trust. } \\
\text { Inquiry and creativity } \\
\text { flow. } \\
\text { Explore personal, work } \\
\text { related or general } \\
\text { topics. }\end{array}$ & $\begin{array}{l}\text { Explore issues of conflict } \\
\text { and social justice. } \\
\text { Explore in/out group } \\
\text { dynamics and issues. }\end{array}$ & $\begin{array}{l}\text { Ask participants } \\
\text { about the main } \\
\text { changes they would } \\
\text { like to see in the } \\
\text { community. } \\
\text { Ask what kind of } \\
\text { public policies can } \\
\text { help. }\end{array}$ & $\begin{array}{l}\text { Continue clarification } \\
\text { of issues. } \\
\text { Probe relationships to } \\
\text { choose direction for } \\
\text { change. } \\
\text { Build scenarios- } \\
\text { experience a change in } \\
\text { the relationship. }\end{array}$ \\
\hline $\begin{array}{l}\text { Moving from } \\
\text { dialogue to } \\
\text { action }\end{array}$ & $\begin{array}{l}\text { Assess experiences. } \\
\text { Explore transfer of } \\
\text { learning and skills into } \\
\text { daily life. }\end{array}$ & $\begin{array}{l}\text { Plan action. } \\
\text { Envision and seek } \\
\text { opportunities for action. } \\
\text { Build alliances. }\end{array}$ & $\begin{array}{l}\text { Ask what participants } \\
\text { will do as individuals } \\
\text { and with others to } \\
\text { make a difference. }\end{array}$ & $\begin{array}{l}\text { Plan action. } \\
\text { Act together to make } \\
\text { change happen. } \\
\text { Monitor and evaluate. }\end{array}$ \\
\hline
\end{tabular}

Adapted from Zúñiga and Nagda (2001: 314-315) 


\section{Results and Discussions}

\section{Types and Designs of Inter-Religious Dialogue}

Based on the cross-model analysis, critical-dialogic education was found to be more salient compared to the other three types of dialogue (i.e., collective inquiry; community building and social action and; conflict resolution and peace building). Therefore, the finding confirms that the existing models of inter-religious dialogue is intellectual in nature rather than cooperative and interactive. The analysis also reveals that the typical dialogue formats applied by the organizations are forum, seminar, conference, public lecture, talks and roundtable discussions. The application of a forum can be seen in STAD (MMU), MPP (USM) and IYC critical-dialogic educational type.

AMEIA's "Understanding World Religions," a program that invited a speaker to discuss on religion he was representing in a particular week, best describes a critical-dialogic education type of dialogue with public lecture format (Informer 1). CCD's "Dialog antara Penganut Agama Mengenai Isu-Isu Semasa" (i.e., conflict resolution and peace building) (Centre for Civilizational Dialogue [CCD], 2008) and INSaF's monthly meeting (i.e., collective inquiry) (Informer 2) that had limited number of participants, normally take the format of roundtable dialogue. In this format, all participants have an equal opportunity to share their thoughts as opposed to the forum, public lecture or seminar format where not all participants have the same opportunity to be involved in the discussion process.

Seven out of ten organizations only included presentation sessions and discussions in most of their programs. However, two organizations, specifically INSaF and IIS applied a slightly different approach in conducting dialogue. Instead of relying on presentation sessions and academic discussions alone, these organizations also included activities that led to bonding among the participants. INSaF for example had included hi-tea session at the end of one of its critical-dialogic educational dialogue programs titled "Karma, Faith and Divinity." This session provided participants with the opportunity to get to know each other better (The Pure Life Society [PLS], 2006).

IIS included a chess competition and sailing activities during the break of its conflict resolution type of dialogue with Hindu Sangam (Informer 3). Table 2 provides a brief overview of the cross-models analysis discussed in this section.

Based on this reality, most of prominent comparative religion and inter-religious dialogue scholars propose that inter-religious dialogue can only be participated by religious leaders, scholars, experts and the like. Al-Faruqi (1992) for instance, asserted that dialogue should be restricted to the elite or intelligentsia since the Muslim grassroots do not have sufficient knowledge to engage Western Christians in the case of Muslim-Christian dialogue.

Likewise, Kamaroniah (2001) also offers further support to this argument when she stresses that only those with competent knowledge and are strongly committed to their religions are allowed to participate in inter-religious dialogue. Based on these conditions, it seems to be only the elite and the intellectuals can reap the benefits of inter-religious dialogue while the grassroots will remain ignorant about the others. 
Nevertheless, the spirit of volunteerism and humanitarianism demonstrated by inter-religious community consisted of the grassroots during the COVID-19 pandemic, provide optimism that the grassroots can also get involved in inter-religious dialogue through dialogue that is integrated with social action. This spirit is consistent with the premises endorsed by Al-Faruqi (1992) and Knitter (1995). These two scholars propose that in order to address the needs of humanity, dialogue should be followed by action or vice versa. The subsequent analysis on stages of dialogue will further explain the symbiosis between dialogue and action. 
INTERNATIONAL JOURNAL OF ACADEMIC RESEARCH IN BUSINESS AND SOCIAL SCIENCES Vol. 11, No. 12, 2021, E-ISSN: 2222-6990 @ 2021 HRMARS

Table 2: Cross-models analysis on types and designs of inter-religious dialogue

\begin{tabular}{|c|c|c|c|c|c|c|c|c|c|c|}
\hline Org. & CCD & IKIM & IPSI & IYC & AMEIA & MPP (USM) & INSaF & MMU & MCCBCHST & IIS \\
\hline Types & $\mathrm{CE}, \mathrm{CR}, \mathrm{Cl}$ & $\mathrm{CB}, \mathrm{CE}$ & $\mathrm{CE}$ & CE & CE & CE & $\mathrm{CE}, \mathrm{CB}, \mathrm{Cl}$ & $\mathrm{CE}$ & $\mathrm{Cl}$ & $\mathrm{CE}, \mathrm{CR}$ \\
\hline $\begin{array}{l}\text { Theme/ } \\
\text { Topic }\end{array}$ & $\begin{array}{l}\text { General, } \\
\text { issue } \\
\text { based, } \\
\text { sensitive }\end{array}$ & $\begin{array}{l}\text { General, } \\
\text { moral }\end{array}$ & General & $\begin{array}{l}\text { General, } \\
\text { theology }\end{array}$ & $\begin{array}{l}\text { General, } \\
\text { theology }\end{array}$ & $\begin{array}{l}\text { General, } \\
\text { theology }\end{array}$ & $\begin{array}{l}\text { General, } \\
\text { theology }\end{array}$ & $\begin{array}{l}\text { General, } \\
\text { theology }\end{array}$ & General & Theology \\
\hline $\begin{array}{l}\text { Participan } \\
t\end{array}$ & $\begin{array}{l}\text { Grassroots } \\
\text { Elite }\end{array}$ & $\begin{array}{l}\text { Grassroots } \\
\text { Elite }\end{array}$ & Grassroots & Grassroots & Grassroots & Grassroots & $\begin{array}{l}\text { Grassroots } \\
\text { Elite }\end{array}$ & Grassroots & Elite & $\begin{array}{l}\text { Grassroots } \\
\text { Elite }\end{array}$ \\
\hline Format & $\begin{array}{l}\text { Seminar, } \\
\text { roundtabl } \\
\text { e }\end{array}$ & $\begin{array}{l}\text { Seminar, } \\
\text { roundtable }\end{array}$ & Seminar & Seminar & Seminar & Seminar & $\begin{array}{l}\text { Seminar, } \\
\text { workshop, } \\
\text { roundtabl } \\
\text { e }\end{array}$ & Seminar & Roundtable & $\begin{array}{l}\text { Seminar, } \\
\text { roundtabl } \\
\text { e }\end{array}$ \\
\hline Goals & $\begin{array}{l}\text { To } \\
\text { promote } \\
\text { generic } \\
\text { skills }\end{array}$ & $\begin{array}{l}\text { To provide } \\
\text { accurate } \\
\text { understandin } \\
\text { g about Islam }\end{array}$ & $\begin{array}{l}\text { To clarify } \\
\text { non-Muslim } \\
\text { misundersta } \\
\text { nding } \\
\text { towards } \\
\text { Islam }\end{array}$ & $\begin{array}{l}\text { To increase } \\
\text { inter- } \\
\text { religious } \\
\text { understandin } \\
\mathrm{g}\end{array}$ & $\begin{array}{l}\text { To expose } \\
\text { Catholics } \\
\text { to other } \\
\text { religions }\end{array}$ & $\begin{array}{l}\text { To increase } \\
\text { inter-religious } \\
\text { understandin } \\
\mathrm{g}\end{array}$ & $\begin{array}{l}\text { To } \\
\text { promote } \\
\text { unity in } \\
\text { diversity }\end{array}$ & $\begin{array}{l}\text { To increase } \\
\text { inter-religious } \\
\text { understandin } \\
\mathrm{g}\end{array}$ & $\begin{array}{l}\text { To discuss } \\
\text { current/work } \\
\text { related issues }\end{array}$ & $\begin{array}{l}\text { To support } \\
d a^{c} \text { wah } \\
\text { activities }\end{array}$ \\
\hline Duration & $\begin{array}{l}\text { Few hours } \\
(\mathrm{CE}, \mathrm{Cl}) \\
2 \text { days }(\mathrm{CR})\end{array}$ & $\begin{array}{l}2 \text { days (CB) } \\
\text { Few hours } \\
\text { (CE) }\end{array}$ & Few hours & Few hours & $\begin{array}{l}\text { 6-7 weeks } \\
\text { for a single } \\
\text { program } \\
\text { (few hours } \\
\text { for a } \\
\text { week) }\end{array}$ & Few hours & $\begin{array}{l}\text { Few } \\
\text { hours }\end{array}$ & $\begin{array}{l}\text { Few hours } \\
(\mathrm{CB}, \mathrm{Cl}, \mathrm{CE})\end{array}$ & Few hours & $\begin{array}{l}\text { Few hours } \\
\text { (CE) } \\
2 \text { days (CR) }\end{array}$ \\
\hline Activities & None & None & None & None & None & None & Activities & None & None & Activities \\
\hline
\end{tabular}

Note. $\mathrm{CB}=$ Community building and social action; $\mathrm{CR}$ = Collective inquiry; $\mathrm{CR}$ = Conflict resolution; $\mathrm{CE}=$ Critical-dialogic education; $\mathrm{NA}=\mathrm{Not}$ Available 


\section{Inter-group Dialogue Stages Analysis}

Stages of dialogue as outlined by Zúñiga and Nagda (2001) serve as a guide or a map for dialogue practitioners when delineating the design of the dialogue. The four stages facilitates the dialogue program to maintain consistency with the main objectives aimed at each stage, to guarantee the transition to following stages and to accomplish the overall goals of dialogue (Zúñiga \& Nagda, 2001). The failure of inter-religious dialogue program to be systematically implemented and comply with the four dialogue stages, will render the ineffectiveness of the inter-religious dialogue program.

The finding reveals that, most of inter-religious dialogue models in Malaysia are identified as a single event in the format of forum, seminar or public lecture. As a matter of fact, intergroup dialogue is described as a process rather than a single event, (Zúñiga \& Nagda, 2001) as it progresses through a series of stages and sustained for eight to twelve facilitated meetings (Zúñiga, et al., 2007).

The analysis using the four stages of dialogue implies that, even though there were some models had fulfilled all four stages, their potential to achieve specific goals in each stage was relatively unfeasible since the transition from one stage to another in a single event needs to occur in a very short period. The finding also reveals that some dialogue models remained at a certain stage and did not progress into the subsequent stages.

This was especially so for the critical-dialogic education type of dialogue. The analysis indicates that most of inter-religious dialogue models (e.g. IYC, IPSI, STAD (MMU) and MPP (USM)) only reached the first, second, and third stage of dialogue. In most cases, the fourth stage which supposed to include action planning and alliance building could not be identified.

As an example, an inter-religious dialogue forum titled "Do All Paths Lead to Paradise?" that was conducted by IYC in 2010 only took few hours (i.e. from 7.30 am to 1.00 pm) (Intellectual Youth Club [IYC], 2010). The fourth stage could not be identified in this forum as it ended with concluding remark by the speakers related to the topic and no further discussion on action planning and alliance building.

IIS's Muslims and Buddhists inter-religious dialogue titled "Sowing Seeds of Understanding and Harmony" that was conducted in 2010 was the only critical-dialogic education type of dialogue that progressed to the fourth stage. There had been a special session that focused on future collaboration between Buddhists and Muslims. The future plans including the initiation of religious talks, visits, youth programs and conducting special question and answer programs (Islamic Information and Services Foundation [IIS], 2010). This was how IIS criticaldialogic education program fulfilled the fourth stage of dialogue.

Inter-religious dialogue program such as "Dialog antara Penganut Agama Mengenai Isu-isu Semasa" organized by CCD, was an example of conflict resolution type of dialogue that had fulfilled all four stages. This closed dialogue led to the development of an action plan to resolve the issues that had been raised. The outcome of the dialogue was forwarded to the related minister and documented for future reference (Centre for Civilizational Dialogue [CCD], 2008). 
Likewise, INSaF's inter-religious dialogue program titled "Hari Raya Celebration and Religious Harmony Workshop" had been identified as the community building dialogue type which conformed to all four stages. Other than workshop and Hari Raya Celebration, this program had also included re-commitment to efforts towards religious harmony which signifies action planning and alliance building (Inter-faith Spiritual Fellowship [INSaF], 2010). Most organizations that were involved in the collective inquiry dialogue type such as MCCBCHST monthly meeting had also fulfilled the criteria required for all dialogue stages (Informer 4).

Even though there were several inter-religious dialogue programs that progressed from the first to the fourth stage, these programs were categorized under the conflict resolution, community building and collective inquiry. Programs identified under the most salient type of dialogue in Malaysia (i.e. critical-dialogic education) however were unable to fulfil all dialogue stages. The summary of inter-group dialogue stages analysis for each organization is shown in table 3.

The fourth stage is the most important stage of dialogue as this is where the action planning and alliance building take place. In order to make inter-religious dialogue more appealing for the grassroots, the focus should be at interaction and cooperation among the participants rather than intellectual discussion. Inter-religious understanding, harmony and other anticipated outcomes of dialogue might be achieved not only through intellectual discussion but also through interaction and cooperation.

The proposition on positive effects of contact which is better known as Contact Theory was first introduced by Gordon Allport (1954). This theory is among major theories that address in-group or out-group bias and provides interventions that reorganize social boundaries (Paluck \& Green, 2009). Allport (1954) suggested that inter-group contact will produce positive effects provided that it fulfils four key conditions:

i. Equal group status within the group encounter

ii. Common goals

iii. Co-operative interactions

iv. Support from those with social influence and power

For this reason, inter-religious dialogue practitioners should consider to include the fourth stage of dialogue which aims at action planning and alliance building since these two activities reflect the application of the Contact Theory. 
INTERNATIONAL JOURNAL OF ACADEMIC RESEARCH IN BUSINESS AND SOCIAL SCIENCES Vol. 11, No. 12, 2021, E-ISSN: 2222-6990 @ 2021 HRMARS

Table 3: Inter-group Dialogue Stages Analysis

\begin{tabular}{|c|c|c|c|c|}
\hline $\begin{array}{l}\text { Stages of } \\
\text { Dialogue }\end{array}$ & $\begin{array}{l}\text { Stage One: Forming and } \\
\text { Building Relationship }\end{array}$ & $\begin{array}{l}\text { Stage Two: Exploring } \\
\text { Differences and Commonalities } \\
\text { of Experience }\end{array}$ & $\begin{array}{l}\text { Stage Three: Exploring } \\
\text { and Discussing Hot Topics }\end{array}$ & $\begin{array}{l}\text { Stage Four: Action } \\
\text { Planning and } \\
\text { Alliance Building }\end{array}$ \\
\hline Organization & & & & \\
\hline CCD & $\begin{array}{l}\text { CE-No clear guidelines } \\
\text { explained } \\
\text { CR- Decide to engage in } \\
\text { dialogue with PANEL and } \\
\text { form group members } \\
\text { Cl- Build an environment for } \\
\text { dialogue for safety and trust } \\
\text { issues to emerge by inviting } \\
\text { Mrs Alia Hogben }\end{array}$ & $\begin{array}{l}\text { CE-Explore multiple perspectives } \\
\text { on certain issues, commonalities } \\
\text { and differences in presentation } \\
\text { sessions } \\
\text { CR-Explore and clarify issues such } \\
\text { as conversion issue } \\
\text { Cl-Dialogue about the selected } \\
\text { topics (e.g., the gap between } \\
\text { Islam and the West) }\end{array}$ & $\begin{array}{l}\text { CE-Explore issues of } \\
\text { conflict during Q \& A } \\
\text { session } \\
\text { CR-Continue clarification } \\
\text { of issues } \\
\text { Cl- Inquiry and creativity } \\
\text { flow }\end{array}$ & $\begin{array}{l}\text { CE-No specific } \\
\text { attention for this } \\
\text { stage } \\
\text { CR-Plan action } \\
\text {-Did not monitor } \\
\text { and evaluate the } \\
\text { program } \\
\text { Cl-Asses } \\
\text { experience } \\
\text {-Explore } \\
\text { transferring } \\
\text { learning and skills } \\
\text { into daily life }\end{array}$ \\
\hline
\end{tabular}




\section{Table 3-Continued}

\begin{tabular}{|c|c|c|c|c|}
\hline IKIM & $\begin{array}{l}\text { CB-Share personal beliefs } \\
\text { and experiences about } \\
\text { particular issue (e.g., } \\
\text { social problems) }\end{array}$ & $\begin{array}{l}\text { CB-Did not discuss the } \\
\text { nature of the problems } \\
\text { (e.g., social problems) }\end{array}$ & $\begin{array}{l}\text { CB-No suggestions on the } \\
\text { possible changes in the } \\
\text { community and potential } \\
\text { public policies that help }\end{array}$ & $\begin{array}{l}\text { No specific attention to } \\
\text { this stage in all types of } \\
\text { dialogue }\end{array}$ \\
\hline & $\begin{array}{l}\text { CE- No specific attention } \\
\text { to this stage }\end{array}$ & $\begin{array}{l}\text { CE- Explore multiple } \\
\text { perspectives on certain } \\
\text { issues, commonalities and } \\
\text { differences in } \\
\text { presentation sessions }\end{array}$ & $\begin{array}{l}\text { CE- Explore issues of } \\
\text { conflict during discussion } \\
\text { session }\end{array}$ & \\
\hline IPSI & $\begin{array}{l}\text { CE-Develop guidelines for } \\
\text { dialogue }\end{array}$ & $\begin{array}{l}\text { CE-Explore multiple } \\
\text { perspectives on certain } \\
\text { issues, commonalities and } \\
\text { differences in } \\
\text { presentation sessions }\end{array}$ & $\begin{array}{l}\text { CE-Explore issues of } \\
\text { conflict during } Q \& A\end{array}$ & $\begin{array}{l}\text { No specific attention to } \\
\text { this stage in this type of } \\
\text { dialogue }\end{array}$ \\
\hline IYC & $\begin{array}{l}\text { CE-Develop guidelines for } \\
\text { dialogue }\end{array}$ & $\begin{array}{l}\text { CE-Explore multiple } \\
\text { perspectives on certain } \\
\text { issues, commonalities and } \\
\text { differences in } \\
\text { presentation sessions }\end{array}$ & $\begin{array}{l}\text { CE-Explore issues of } \\
\text { conflict during } Q \& A\end{array}$ & $\begin{array}{l}\text { No specific attention to } \\
\text { this stage in this type of } \\
\text { dialogue }\end{array}$ \\
\hline AMEIA & $\begin{array}{l}\text { CE-Begin relationship } \\
\text { building during small } \\
\text { group discussion }\end{array}$ & $\begin{array}{l}\text { CE-Explore multiple } \\
\text { perspectives on certain } \\
\text { issues, commonalities and } \\
\text { differences in } \\
\text { presentation sessions }\end{array}$ & $\begin{array}{l}\text { CE-Explore issues of } \\
\text { conflict during } Q \& A\end{array}$ & $\begin{array}{l}\text { No specific attention to } \\
\text { this stage in all types of } \\
\text { dialogue }\end{array}$ \\
\hline
\end{tabular}


Table 3-Continued

\begin{tabular}{|c|c|c|c|c|}
\hline \multirow[t]{5}{*}{ INSaF } & \multirow{4}{*}{$\begin{array}{l}\text { CE-Relationship building } \\
\text { during activities such as Hi- } \\
\text { tea occurred at the end of } \\
\text { dialogue not in stage one } \\
\text { CB-Share personal beliefs } \\
\text { and experiences about } \\
\text { particular issue (e.g., } \\
\text { Religious harmony in } \\
\text { practical ways at school, } \\
\text { home, workplace and } \\
\text { places of worship) }\end{array}$} & \multirow{5}{*}{$\begin{array}{l}\text { CE-Explore multiple } \\
\text { perspectives on certain } \\
\text { issues, commonalities and } \\
\text { differences in presentation } \\
\text { sessions } \\
\text { CB-Discuss the nature of } \\
\text { problems in inter- } \\
\text { religious/inter-ethnic } \\
\text { relation } \\
\text { CI-Dialogue about current } \\
\text { or work related issues }\end{array}$} & \multirow{3}{*}{$\begin{array}{l}\text { CE-Explore issues of conflict } \\
\text { during Q\&A } \\
\text { CB-Discuss about the } \\
\text { changes in inter-religious } \\
\text { relation at school, home, } \\
\text { workplace and places of } \\
\text { worship that participants } \\
\text { would like to see }\end{array}$} & \multirow{2}{*}{$\begin{array}{l}\text { CE-No specific attention for } \\
\text { this stage } \\
\text { CB-Ask participants how } \\
\text { they will make a difference }\end{array}$} \\
\hline & & & & \\
\hline & & & & $\begin{array}{l}\text { Cl-Asses experience } \\
\text { related to the topic } \\
\text { discussed }\end{array}$ \\
\hline & & & $\begin{array}{l}\text { Cl-Further explore the } \\
\text { issues }\end{array}$ & \\
\hline & $\begin{array}{l}\mathrm{Cl} \text { Develop consensus } \\
\text { among members }\end{array}$ & & & \\
\hline MPP (USM) & $\begin{array}{l}\text { CE-Develop guidelines for } \\
\text { dialogue }\end{array}$ & $\begin{array}{l}\text { CE-Explore multiple } \\
\text { perspectives on certain } \\
\text { issues, commonalities and } \\
\text { differences in presentation } \\
\text { sessions }\end{array}$ & $\begin{array}{l}\text { CE-Explore issues of conflict } \\
\text { during Q \& A }\end{array}$ & $\begin{array}{l}\text { No specific attention to this } \\
\text { stage in this type of } \\
\text { dialogue }\end{array}$ \\
\hline MMU & $\begin{array}{l}\text { CE- Develop guidelines for } \\
\text { dialogue }\end{array}$ & $\begin{array}{l}\text { CE-Explore multiple } \\
\text { perspectives on certain } \\
\text { issues, commonalities and } \\
\text { differences in presentation } \\
\text { sessions }\end{array}$ & $\begin{array}{l}\text { CE-Explore issues of conflict } \\
\text { during } Q \& A\end{array}$ & $\begin{array}{l}\text { No specific attention to this } \\
\text { stage in this type of } \\
\text { dialogue }\end{array}$ \\
\hline MCCBCHST & $\begin{array}{l}\text { Cl-Form group consensus } \\
\text { on certain topic in the } \\
\text { monthly meeting }\end{array}$ & $\begin{array}{l}\text { Cl-Dialogue about current } \\
\text { or work related topics }\end{array}$ & $\begin{array}{l}\text { Cl- Further explore the } \\
\text { issues }\end{array}$ & $\begin{array}{l}\text { Cl-Assess experience } \\
\text { related to the topic } \\
\text { discussed }\end{array}$ \\
\hline
\end{tabular}


INTERNATIONAL JOURNAL OF ACADEMIC RESEARCH IN BUSINESS AND SOCIAL SCIENCES

Vol. 11, No. 12, 2021, E-ISSN: 2222-6990 @ 2021 HRMARS

Table 3 -Continued

IIS CE-Develop guidelines

for dialogue

CR- Decide to engage in dialogue (e.g., Interfaith dialogue with Hindus groups)
CE-Explore multiple
CE-Explore issues
of CE-Plan action
-Envision and
seek
issues, commonalities
and differences in
CR-Continue
opportunities for action and
presentation sessions
clarification of issues
CR-Explore and clarify
issues of concern and
build alliances
CR-Plan action
-Did not monitor
evaluate the program

Note. $\mathbf{C B}=$ Community building and social action; $\mathbf{C R}=$ Collective inquiry; $\mathbf{C R}=$ Conflict resolution; $\mathbf{C E}=$ Critical- dialogic education 


\section{Conclusions}

This research has proven that the main goal of most inter-religious dialogue programs in Malaysia is sharing and exchanging religious knowledge and values through forum, public lecture and other formats that are more synonymous with intellectual discourse. For this reason, this type of dialogue was categorized as critical-dialogic education. The nature of this type of dialogue can be considered as intellectual thus limit the participation from the grassroots in general. Based on the dialogue stages analysis, present study reveals, most of the existing models of inter-religious dialogue especially the critical-dialogic education missed the fourth stage (i.e., the most significant stage for cooperation and social action).

In order to ensure the grassroots can be involved in inter-religious dialogue, this study suggests that, the existing models of inter-religious dialogue should focus on community building and social action type of dialogue instead of critical-dialogical education type. Additionally, the existing model of inter-religious dialogue should also be redesigned and integrated with cooperation and social action. The desired outcomes of inter-religious dialogue such as increased level of inter-religious understanding and harmony can also be achieved through cooperative interaction and working together towards a common goal as suggested by the Contact Theory (Allport, 1954).

The efforts mobilized by inter-religious groups during COVID-19 humanitarian missions were good examples of social action that can be integrated in the inter-religious dialogue. The existing paradigm of inter-religious dialogue in Malaysia revolves around intellectual discourse, forum or public lecture where there is no conducive environment for the participants to engage in cooperative interaction. Present study offers a novel and systematic approach to inter-religious dialogue that integrates intellectual discourse and social action. In order to guarantee the effectiveness of inter-religious dialogue, dialogue practitioners in Malaysia should also consider to employ socio-psychological framework such as the intergroup dialogue stages as proposed by Zúñiga and Nagda (2001) and the Contact Theory (Allport, 1954) in designing their inter-religious dialogue model in addition to the theological framework.

\section{References}

Atalia, O. (2017). Interreligious Action as a Driver for Social Cohesion and Development. In T. Bamat, N. Bolton, M. Leguro, \& Atalia Omer (Eds.), Interreligious Action for Peace Studies in Muslim-Christian Cooperation (pp. 1-20). Catholic Relief Services

Al-Faruqi, I. R. (1992). Islam and Christianity: Diatribe or dialogue. In L. Swidler (Ed.). Muslims in dialogue: The evolution of a dialogue (pp. 1-35). The Edwin Mellen Press.

Allport, G. W. (1954). The nature of prejudice. Mass: Addison-Wesley.

Azizan, B. (2008). Peranan dialog peradaban di dalam wacana "Tamadun Malaysia" [The role of civilizational dialogue in the discourse of "Malaysia Civilization]. Jurnal peradaban. Vol. 1, 1-14.

Bryman, A. (2008). Social research methods ( $3^{\text {rd }}$ edn.). Oxford University Press.

Center for Civilizational Dialogue (CCD). (2008). Report on "Dialog antara penganut agama mengenai isu-isu semasa" [Dialogue among religious adherents on current issues].

Corpuz, J. C. G. (2020). Religions in action: the role of interreligious dialogue in the COVID-19 pandemic. Journal of Public Health, 43(2), e236-e237. 
Fletcher, C. D. (2012). Muslim Interfaith Dialogue in the Twenty-first Century: Building on the Contributions and Legacy of Ismail al-Faruqi. In I. Yusuf (Ed.). Islam and Knowledge: Al Faruqi's Concept of Religion in Islamic Thought (pp.157-176). I.B. Tauris

Gall, M. D., Borg, W. R., \& Gall, J. P. (1996). Educational research: An introduction. White Plains. Longman.

Ghazali, B. (2005). Dialog antara Agama di Malaysia [Inter-religious dialogue in Malaysia]. Pusat Dialog Peradaban. Kuala Lumpur: Universiti Malaya.

Haney, M. S. (2009). Envisioning Islam: Imam Mohammed and Interfaith Dialogue. The Muslim World, 99(4), 622-633.

Intellectual Youth Club. (2010). Report on Do all paths lead to Paradise? Inter-faith Spiritual Fellowship. (2010). Religious harmony workshop.

http://insafpls.wordpress.com/2010/09/06

/religious-harmony-workshop/

Islamic Information and Services Foundation. (2010). Sowing seeds of understanding \& harmony (an inter-faith dialogue between Muslims \& Buddhists). http://www.iis.org.my/2010/07/

Jabatan Kemajuan Islam Malaysia. (2020). Misi bantuan tabung musa'adah Covid-19 JAKIM di Kampung Orang Asli. https://www.facebook.com/MyJAKIMmalaysia/posts/misibantuan-tabung-musaadah-covid-19-jakim-di-kampung-orang-asli-sepangselango/308647482806973

Khadijah, M. K. (2005). Interaksi dan dialog agama (Dialog Peradaban): Satu paparan [Interaction and religious dialogue (Dialogue of civilisations): An overview]. In Azizan Baharuddin (ed.). Islam dan dialog peradaban: Satu perspektif (pp. 91-121). Universiti Malaya: Pusat Dialog Peradaban.

Khairulnizam, M. K., \& Suzy, A. S. (2012, September). The role of inter-faith dialogue in societal development: Malaysian experience. Paper presented at World Conference on Islamic Thought 2012: Contemporary Challenges and Realities organized by Kolej Universiti Islam Sultan Azlan Shah, Perak.

Knitter, P. F. (1995). One earth, many religions: Multifaith dialogue and global responsibility. Orbis Books.

Lochhead, D. (1988). The dialogical imperative: A Christian reflection on inter-faith encounter. Orbis Books.

Malaysia Hindu Sangam Penang State Council (MHSPSC). (2020, March 26). Zero Hunger Programme (Covid-19).

https://www.facebook.com/1474050992641964/posts/zero-hunger-programmecovid-19-rice-packet-distribution-by-welfare-committee-of-/2971130162934032/

Merriam, S. B. (1998): Qualitative research and case studies applications in education. Jossey-Bass Publications.

Miles, M. B., \& Huberman, A. M. (1994). Qualitative data analysis: An expanded sourcebook $\left(2^{\text {nd }}\right.$ ed.). Thousand Oaks, CA: Sage.

Nair, V. (2021, June 2). Devices to help monitor health of those under home quarantine. The Star. https://www.thestar.com.my

Paluck, E. L., \& Green, D. P. (2009). Prejudice reduction: What works? A review and assessment of research and practice. Annual Review of Psychology, 60, 339-367.

Patton, M. Q. (1990). Qualitative evaluation and research methods (2 ${ }^{\text {nd }}$ ed.). Sage Publications. 
Rahimin, A. R., Mohd A. R., Paizah, I., \& Norhayati, M. D. (2011). Dialog antara agama: Realiti dan prospek di Malaysia [Religious dialogue: Its reality and prospect in Malaysia]. Kajian Malaysia, 29(2), 91-110.

Stake, R. (2000). Case studies. In N. Denzin \& E. Lincoln (eds.), Handbook of qualitative research ( $2^{\text {nd }}$ edn., pp. 435-454). Thousand Oaks, CA: Sage.

Taiwan Buddhist Tzu Chi Foundation Malaysia (TBTCFM). (2020). Covid-19 response efforts. https://www. tzuchi.my/en/covid-19/welove-wecare

The Malaysian Church of Jesus Christ of Latter-day Saints (TMCJCLS). (2020). Church in Malaysia provides Covid relief. https://newsmy.churchofjesuschrist.org/article/church-in-malaysia-provides-covid-relief

The Pure Life Society (TPLS). (2006). Truth alone triumph: The pure life society bulletin.

United Nations Children's Fund (UNICEF). (2020, April 7). Launch of global multi-religious faith-in-action Covid-19 initiative: faith and positive change for children, families and communities. https://www.unicef.org/press-releases/launch-global-multi-religiousfaith-action-covid-19-initiative

Yin, R. K. (2003). Case study research: Design and methods ( $3^{\text {rd }}$ edn.). Thousand Oaks, CA: Sage.

Zúñiga, X., \& Nagda, B. A. (2001). Design considerations for inter-group dialogue. In D. Schoem and S. Hurtado (eds.). Inter-group dialogue: Deliberative democracy in school, college, community and workplace (pp. 306-327). University of Michigan Press.

Zúñiga, X., Nagda, B. R. A., Chesler, M., \& Cytron-Walker, A. (2007). Inter-group dialogue in higher education: meaningful learning about social justice. ASHE Higher Education Report. 32(4). Josey Bass. 